\title{
Resilience of Ecosystems to Climate Change
}

\author{
Mengistu Asmamaw 1, *, Argaw Ambellu², Seid Tiku² \\ ${ }^{1}$ Department of Biology, Debre Berhan University, Debre Berhan, Ethiopia \\ ${ }^{2}$ Department of Environmental Health Sciences and Technology, Jimma University, Jimma, Ethiopia
}

Email address:

mengistilash99@gmail.com (M. Asmamaw),aambelu@yahoo.com (A. Ambelu)

To cite this article:

Mengistu Asmamaw, Argaw Ambellu, Seid Tiku. Resilience of Ecosystems to Climate Change. American Journal of Environmental Protection. Vol. 4, No. 6, 2015, pp. 325-333. doi: 10.11648/j.ajep.20150406.19

\begin{abstract}
Human-induced climate change is occurring as an unprecedented rate resulting in ecosystem deterioration and biodiversity loss. Climate change exacerbates environmental hazards, ecosystem modification as well as loss of biological organisms. Anthropogenic releases of greenhouse gases, mainly $\mathrm{CO}_{2}$ has warmed the Earth's surface. The average global temperature has risen more linearly for the last 100 year $(1906-2005)$ by $0.74^{\circ} \mathrm{C}\left(.56-0.92^{\circ} \mathrm{C}\right)$; than the corresponding period (1901-2000) of $0.6^{\circ} \mathrm{C}\left(0.4-0.8^{\circ} \mathrm{C}\right)$. The objective of this review was to examine the potentials of ecosystems in mitigating climate change and in building resilience. A review of relevant literature was employed as possible approach to compile this document. Ethiopia is an agrarian country where agriculture is both the cause and victim to extreme climate variability like elevated temperature and precipitation fluctuation. These have resulted recurrent drought, flooding and reduction in agricultural productivity as a whole. The occurrence and spatial distribution of drought is projected to continue in the upcoming future. The effects of climate variability significantly reduced farmers' adaptive capacity while exacerbating their vulnerability to further weather events. The current trends of ecosystem degradation could not be controlled only through protection of parks. Instead, it involves a large-scale and integrated approach addressing the whole land and sea-escapes. This large scale and integrated ecosystem management approach conserves biodiversity, builds system resilience as well as to ensures the sustainable production of ecosystem services from which the majorities of the rural poor depend on. Resilient ecosystems have a wide range of biodiversity and ecosystem services, resist and recover from extreme events more quickly and are potential to mitigate and adapt to climate change while sustaining livelihoods. Thus, ecosystem based approach through adaptation and mitigation is instrumental to maintain ecosystem health so as to sustain system resilience in the face of climate change.
\end{abstract}

Keywords: Adaptation, Climate Change, Ecosystem, Mitigation, Resilience

\section{Introduction: Climate Change and Consequences}

\subsection{Current Trends and Future Projections of Climate Change}

Human-induced climate change is occurring [33, 35, 39] as an unprecedented rate resulting in considerable consequences on ecosystems and human well-being [32, 39, 43]. Anthropogenic releases of greenhouse gases, mainly carbon dioxide $\left(\mathrm{CO}_{2}\right)[35]$ has warmed the Earth's surface. Eleven of the last twelve years (1995-2006) rank among the warmest years in record of global surface temperature since 1850 . The average global temperature has risen more linearly for the last 100 year $(1906-2005)$ by $0.74^{\circ} \mathrm{C}$; than the corresponding period (1901-2000) of $0.6^{\circ} \mathrm{C}$ (Fig.3). As a result, this period $\left(20^{\text {th }} \mathrm{c}\right)$ is the largest and fastest warming period of the planet [35] leading to occurrences of extreme weather events, such as rising sea-levels, recurrent droughts, intensive hurricanes and floods, etc. [49].

In line with atmospheric temperature, global sea level was increased at average rate of $1.8 \mathrm{~mm} / \mathrm{yr}$ and at $3.1 \mathrm{~mm} / \mathrm{yr}$ since 1961 and 1993, respectively. This has resulted in thermal expansion, melting of glaciers and ice caps, and polar ice. On the other hand, Arctic sea ice has reduced by 2.7 percent per decade since 1978; where a reduction by 7.4 percent per decade was recorded during summer seasons [35] (Fig 1).

\subsection{Consequences of Climate Change}

Climate change is a universal challenge; threatening 
ecosystems, biodiversity and livelihoods. However, it becomes worse particularly affecting the developing poor who dependence on climate-sensitive sectors, such as agriculture, livestock and eco-tourism for their survival [35] and is highly vulnerable and suffer from the effects of environmental changes [2, 57, 35]. Some common climateinduced impacts are presented as follows.

\subsubsection{Climate Change Increases the Risks of Climate- Related Disasters}

Climate-induced hazards, such as floods, storms, landslides, droughts, etc. are risks to all nations throughout the world damaging ecosystems, humans, and their economies; thereby deteriorating social-ecological resilience [49]. Their occurrence and intensity are expected to continue in the future even causing magnified disaster risks [35], reducing ecosystem's resilience against the effects of climate change [74]; whilst increasing risk of disasters [35, 49]. The number of climate-induced disasters for the last 70 years has been illustrated in figure 2 and shows climate related extreme events are sharply increasing since 1960s and their occurrences dramatically accelerated rapidly since 1990s Fig. 2 [49].

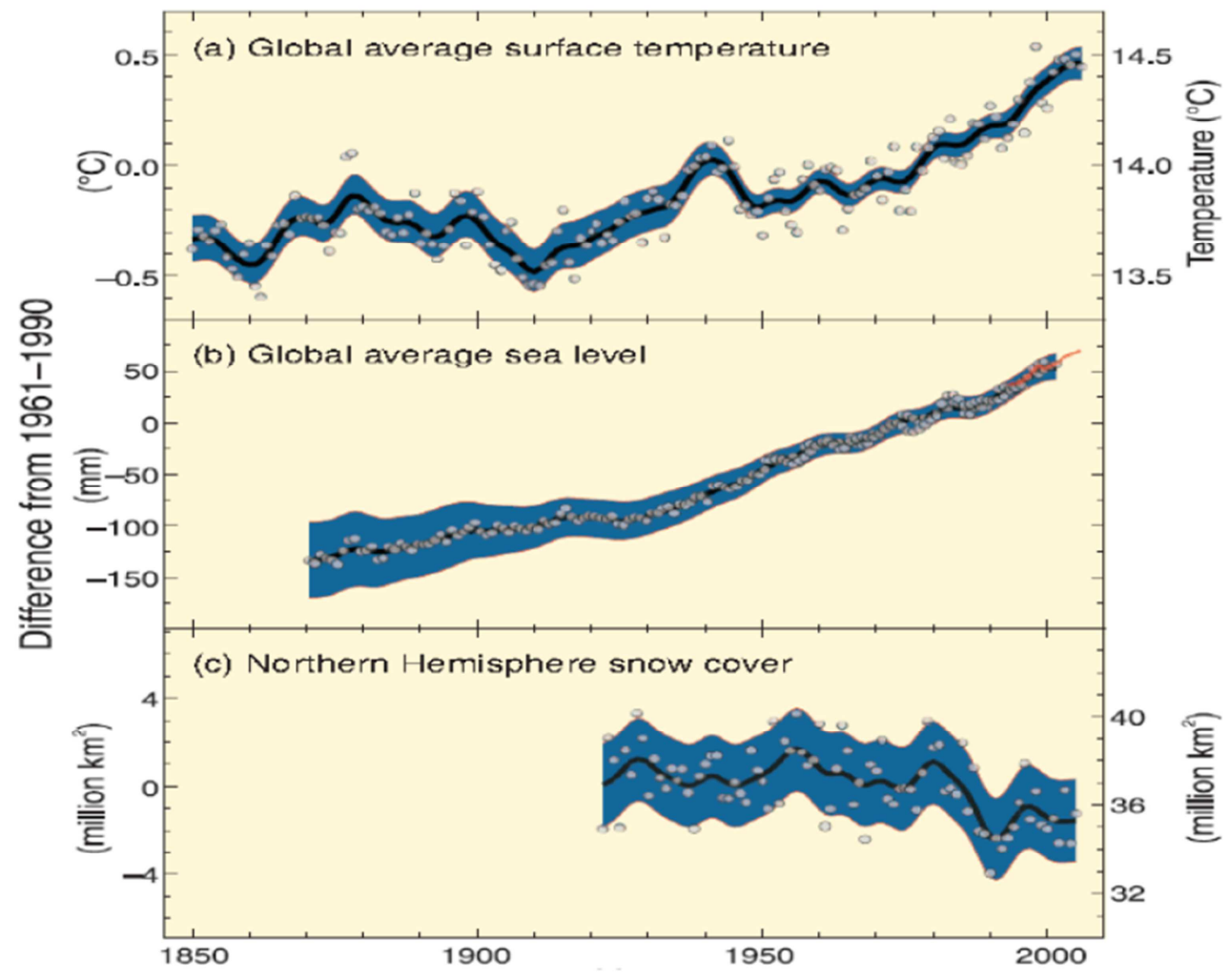

Figure 1. Changes in Temperature, Sea level and Northern Hemisphere Snow cover [35].

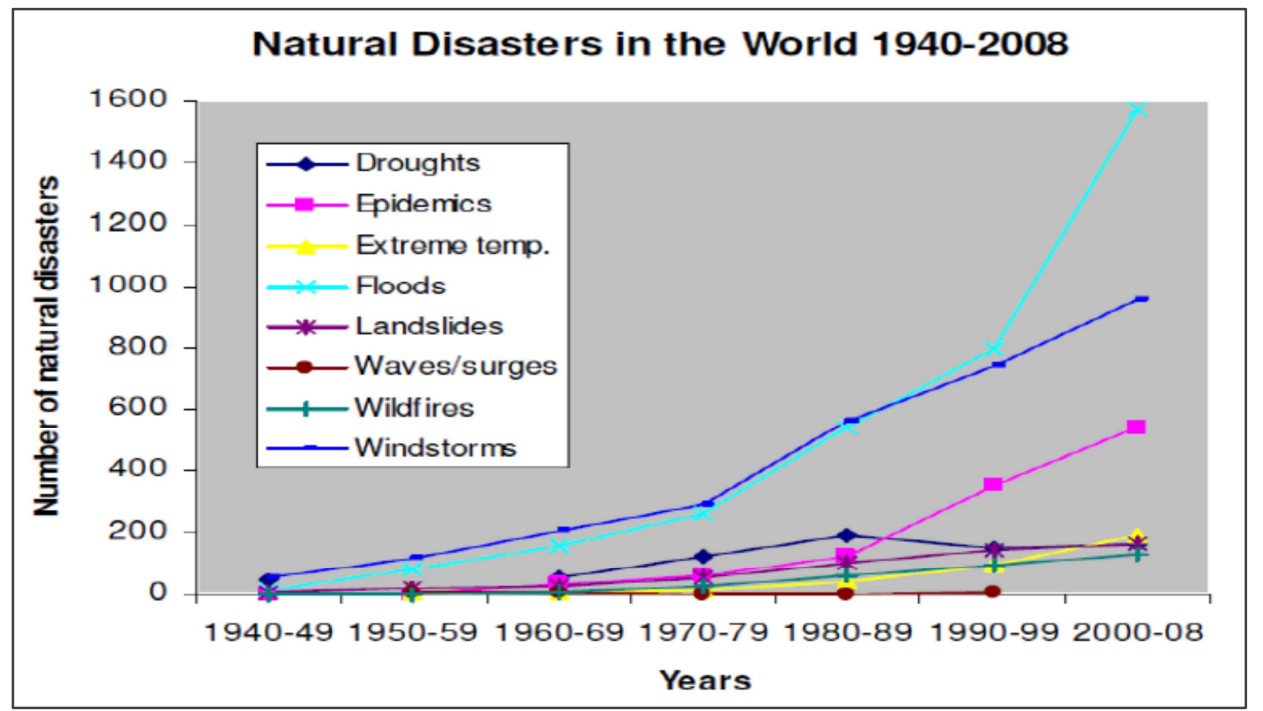

Figure 2. Number of Climate-induced Disasters in the World during 1940s to 2008 (Source: International Disaster Database cited in [49]). 


\subsubsection{Climate Change Exacerbates Ecosystem Degradation and Biodiversity Loss}

The socioeconomic and biophysical environment of the Earth is rapidly changing [38]; particularly for the last five decades [47, 14]. It could not be denied that ecosystem changes have contributed to societal developments. However, they have resulted in environmental degradation by deteriorating ecosystem services, aggravating environmental changes and vulnerability $[47,14]$.

For instance, the Global Biodiversity Outlook-3, published by the Convention of Biological Diversity in 2010 reveals that natural habitats are shrinking significantly during the last century all over the world; where mangroves, forests and wetlands declined by $35 \%, 40 \%$ and $50 \%$, respectively [58]. Consequently, one third of the abundance of vertebrates has been declined and almost a quarter of plant species are likely to be threatened with extinction during the period of 1970 to 2006 [16].

Climate change triggers ecosystem transformation, biodiversity loss [12] and substantial modifications of ecosystem services [47]. The structure and function of terrestrial, freshwater and marine ecosystems are considerably changing [49]. For instance, about 60 percent of ecosystem services and almost 70 percent of regulating and cultural services have been degraded and over-exploited globally [47]. It is predicted that drivers to social-ecological transformation [47] and associated consequences on ecosystems and biodiversity are expected to become stronger and complex in the future [11, 42, 35] (Fig 3).

\section{Vulnerable Communities}

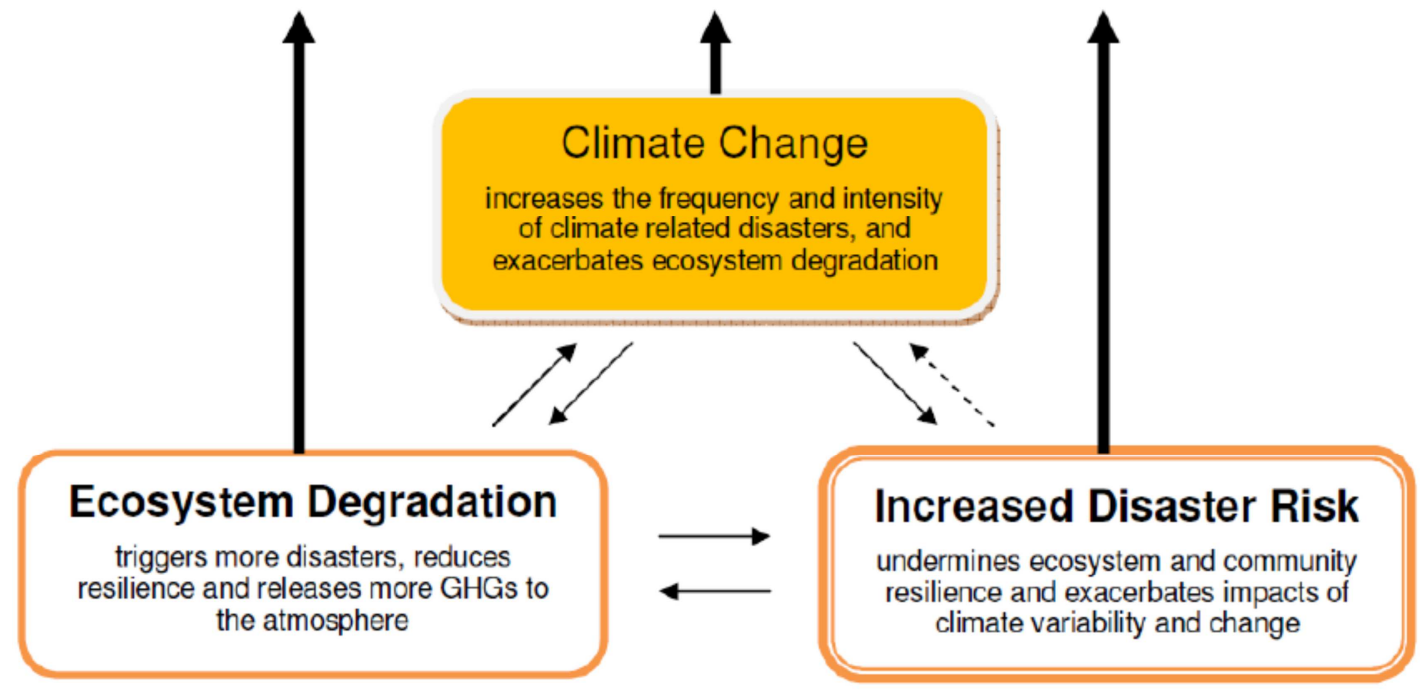

Figure 3. Simplified Illustration of the Interaction between Climate Change, Ecosystem Degradation and Disaster Risk (source: [64]).

\subsubsection{Climate Change Impacts on Human Communities and Livelihoods}

Climate change is threatening the agriculture, tourism, resource management, industry, water resources, health and others [64]. For instance, fluctuation in frequency and severity of extreme climate events has profound impacts on food and forestry production, availability of water and fodder, as well as on the health and productivity of the whole ecosystem [22]. It is predicted that the food production will be in 5 to $25 \%$ short of demand and price is expected to rise in $30-50 \%$ by 2050 [ 51$]$.

Scientific evidences disclose that climate change has substantial impacts on crop productivity and associated food security [28, 73]. In Africa for example, around 75-250 millions of people are expected to be vulnerable to climateinduced water stress by 2020 ; a $50 \%$ decline in agricultural yields in 2020; lowland densely populated areas will suffer from sea level rise; and an estimated temperature rise of arid and semi-arid regions in $5-8 \%$ by 2080 [35]. Moreover, the Sahel experiences worldwide prominence, where more than 300,000 humans and millions of animals died, during the catastrophic drought of the early 1970s [48].

\subsection{Climate Change in Ethiopia}

Ethiopia is an agrarian country located in the Horn of Africa where agriculture constitutes 52 percent of the gross domestic product, absorbs 80 percent of labor force and generates more than 85 percent of the foreign exchange earnings [17]. The sector is the principal source of food production and prime contributor to food security [15]. Agriculture is often rain fed, traditional subsistence smallscale mixed crop and livestock production (8 million households) with minimal agricultural productivity; where irrigation accounts only one percent of the arable land area of the country. Trends like traditional farming system, soil 
degradation, poor complementary services like extension, credit, marketing, infrastructure and climatic factors, such as recurrent drought and flood have been identified as the major limiting factors that hinder agricultural productivity in the country $[20,3,5,75]$. These factors are responsible to lessen adaptive capacity by increasing the vulnerability of farmers to forthcoming uncertainty such as climate change that affect the efficiency of the agriculture [19]. Due to its limited adaptive capacity, the country has been placed as among the most vulnerable countries in Africa in recent mapping of vulnerability and poverty in Africa [61].

Historically, Ethiopia has experienced five major droughts since 1980s [1].The effects of climate change in Ethiopia are not restricted only to recurrent droughts [40]; instead fluctuations in other critical climatic variables are apparent highlighting the multifarious consequence of climate [61]. For instance, the average minimum and maximum temperature of the country has risen by $0.25^{\circ} \mathrm{C}$ and $0.1^{\circ} \mathrm{C}$, respectively during the last decades. Climate prediction models show that temperature in Ethiopia continues rising in the next years [59].It is projected that the mean temperature will rise by $1.7-2.1^{\circ} \mathrm{C}$ by 2050 and $2.7-3.4^{\circ} \mathrm{C}$ by 2080 [60]. Most models are consistent with increasing patterns of temperature. However, depending on the type of models used, both increasing and decreasing patterns are projected in precipitation forecasts [59]. However, [19] disclose that rainfall pattern has showed an extreme variability during the last 50 years. Furthermore, the occurrence and spatial distribution of drought has been intensified during the last decades as well as projected to continue in the upcoming [40].

This study was designed to highlight the current states of climate change and variability with a special emphasis in developing countries including in Ethiopia as well as to assess the potential of ecosystems in mitigating the effects of climate change and in building system resilience. Review approach was used to compile this study and more than 168 literatures were collected where most relevant 75 of them were selected and analyzed in this study.

\section{Managing Landscapes for Ecosystem Resilience}

The etymology of the word "resilience" comes from Latin "resilire" to mean "to spring back" or "to rebound" and described as springiness or elasticity. The term resilience was introduced into ecological studies in late 1950s and denoted as the amplitude of changes brought about by disturbance and the dynamics of post disturbance recovery [25].

The landmark for the application of resilience to ecosystems is laid by [30]. Nowadays, the term has different definitions and applied in various disciplines, including: ecology, sociology, economics, psychology and political science and engineering science [27,9]. It is the capacity of an ecosystem to absorb change and re-organize itself, whilst undergoing change, in order to retain its character and ecological functioning [10].The basic notion for resilience thinking is the likely of ecosystem crossing a threshold or tipping point, beyond which it will become fundamentally, and often irreversibly different [70].

Resilience in social-ecological systems refers the capacity of a system to absorb disturbances and identifies the ongoing changes so as to still maintain the same function, structure, identity and feedbacks [70]. It is the tendency to avoid basic long term changes in main characteristics, like level of primary productivity and to maintain fertile soil (ecological system) or the presence of efficient livelihood alternatives and health care (social system) [50].

Ecosystem resilience is also defined as the capacity of an ecosystem to withstand perturbations without losing any of its functional properties. Currently, resilience denotes the capacity of a system (e.g. a community, society or ecosystem) to cope with disturbances (e.g. financial crises, floods, drought, hurricane, tsunami or fire) without shifting into a qualitatively different state [29]. A resilient system has the potential to cope with shocks, surprises and recover from disturbances; as resilience is both the capacity of a system to deal with change and continue functioning $[8,9]$.

\subsection{Characteristics of Resilient Ecosystem}

Basic characteristics of resilient ecosystem are summarized as follows [4].

Diversity and redundancy

Diversity is recognized as the most determinant factor to contribute resilience and more frequently cited by several authors [13, 27, 30, 55]. Sustaining diverse functional groups within ecosystem maintains ecosystem health and assists sustainability [30].The existence of different groups of organisms performs different functions and balance major components of an ecosystem which will be supportive in preventing the loss of key ecological resources [4]. [7] explained the concept of response diversity pointing that higher functional diversity enhances an ecosystem to be more resilient to disturbances; hence different organisms respond to disturbances in different mechanisms. Redundancy is the ability of different species to carry out similar activity. This redundancy property of a system is instrumental as the loss of certain system components doesn't jeopardize the whole system; instead it allows sustaining the function of a system to continue even with shocks [24].

Participation and community engagement

The contributions of community engagement, ownership, participation and indigenous/local knowledge to socialecological resilience have been reported in different scholars $[44,45,52,6,54,7]$. Studies underline that community participation is supportive in building legitimacy, promoting monitoring and enforcement, enhance recognition of system dynamics as well as encourage system's capacity to sense changes [7]. Therefore, participation of local communities, particularly who largely benefited from ecosystem services, influence the success of ecosystem management [7]; promotes belongingness [4] and is essential to maintain ecosystem health [54]. 


\section{Polycentricism, decentralization and flexibility}

Ecosystems exhibiting flexible, decentralized and well integrated management of different local and regional institutions maintain sustainability and resilience $[27,54,56$, 7]. Unlike the command and control approach of ecosystem management, decentralized management allows the incorporation of scale specific knowledge in major decisions to regulate ecosystem health [7]. This strategy is supportive for management flexibility of ecosystems and maintains the system not to tip over dis-functionality [52].

Learning, experimentation and innovation

Ecosystem management and associated resilience of ecosystem is critically determined by learning and experimentation. It is understood that change and uncertainty are an unavoidable in any ecosystems. Consequently, continual learning and knowledge revision is essential to effective ecosystem management [7]. This characteristic is especially important where ecosystems are restored from disturbances, as they are more vulnerable to similar shocks. Learning from experiences ensures that a system capable to bounce back better and resist if similar disturbances exist again [18].

Connectivity, networks and cross-scalar linkages

Connectivity is the extent in which resources, species or social actors disperse, migrate or linked to ecological and social landscapes [7]. In the context of ecosystem management, connections and networks can build resilience, as it enables a system to quickly either restore or prepared for changes [52]. In building community resilience to disasters, great interrelation across scales of governance during early warning systems results in enhanced resilience to disaster [63].

\subsection{Resilience, Vulnerability and Adaptive Capacity}

Vulnerability is antonym to resilience and refers to the degree of sensitivity that associates the ecosystem services to global changes and also the degree to which sectors, such as agriculture, forestry, water management, energy and nature conservation relying on ecosystem services is unable to adapt to the changes [37,33]. Anthropogenic disturbances such as rigorous land use change makes species and their habitats vulnerable [46].Vulnerability to climate change is the degree to which a system is subject to/or unable to acclimatize adverse effects of climate change, including climate variability and extremes [33].

Vulnerability is central concept to adaptation and is dependent up on exposure, sensitivity, and adaptive capacity of a system. For instance, high exposure or sensitivity and low adaptive capacity induces high vulnerability of a system to environmental changes [41]. Sensitivity is the degree to which a system is affected, either adversely or beneficially, by climate-related stimuli. Adaptive capacity is the ability of a system to adjust to climate change (including climate variability and extremes), to moderate potential damage, to take advantage of opportunities, or to cope with the consequences [33,35]. Adaptive management is not only maintains ecological stability but also builds more flexible institutions for resource management [31].
Resource management strategies through ecosystem-based approaches are crucial to lessen vulnerability of ecosystems and promote resilience of the communities who depend on natural resources [31]. The ecosystem concept argues that proper planning along with ecosystem changes whilst considering the role of human behavior on the environment is essential over temporal and spatial scales [62].

\section{Working on Ecosystems to Mitigate Environmental Changes}

Ecosystem approach is a strategy for the integrated management of land, water and living resources that promotes conservation and sustainable use in an equitable way. It is instrumental in increasing ecological connectivity with a view to increasing resilience, and contributes to address conservation objectives [21]. Ecosystem-based approaches are cost-effective, accessible to rural poor, contribute to relieve poverty and promote sustainable development [26, 49]. Ecosystem based approach is a win-win approach with multifaceted benefits and summarized as follows.

\subsection{Ecosystem-Based Approach Enhances Climate Change Adaptation and/or Mitigation and for Disaster Risk Reduction}

Disaster risk reduction is a practice of reducing disaster risks through reducing exposure to hazards, reducing vulnerability of social-ecological system, wise management of land and the environment and improves preparedness for adverse events [68]. Adaptation contributes to disaster risk reduction in being prepared for climate related impacts; whereas, disaster risk reduction is crucial to adaptation and it serves as a basis to achieve long-lasting climate impacts. Both climate change adaptation and disaster risk reduction rely on regulating services of ecosystems and are instrumental to build ecosystem health and resilience [53, 69].

The IPCC defines climate change adaptation as an adjustment in natural or human systems in response to actual or expected climatic stimuli or their effects, which moderates harm or exploits beneficial opportunities [33]. It is the use of natural capital by humans to acclimatize to climate change impacts; that in turn possesses manifold cobenefits for mitigation, protection of livelihoods and poverty alleviation [50].

The basic objective of adaptation is to lower humans/ecosystems vulnerability to the harmful effects of climate change (sea level rise, rising temperature, rainfall variability, drought, flood, etc.); instead creates an opportunity on existing weather events (increasing ecosystem productivity) [36]. It is a strategy designed to address the fundamental relations between climate change, biodiversity and sustainable resource management and can be functional in both developing and developed nations [50].

Adaptation options range from technological like in increasing sea defense or flood-proof houses on stilts, to 
behavioral changes at individual level, for instance reducing water utilization during drought, using mosquito net (insecticide-sprayed) to prevent mosquito bites. Besides, improved water management system, improved risk management, biodiversity conservation, early warning for extreme events and establishing insurance options are also adaptation strategies mostly recommended to the societies $[65,66]$.

Mitigation is an anthropogenic intervention involving reducing greenhouse gases concentration either by reducing their generation (burning of fossil fuels, heat or transport) or improving the potentials of their sinks (oceans, wetlands, forests and soil) to reduce the impacts of climate change [34]. The main purpose of mitigation is to avoid the unsafe human intervention in the climate systems and to maintain the concentration of greenhouse gases in level where ecosystems able to adapt naturally to climate change; so as to ensure the health and productivity of social-ecological system [36].

Mitigation action is crucial to lessen new emissions and/or enhance sinks. However, it should be integrated with adaptation [35] and implemented in broader development objectives, such as economic development, energy security, public health, air quality and local environmental protection for enhanced response to climatic impacts [67, 65, 64]. Sustainable management of key biological resources and habitats through mitigation and adaption strategies is helpful especially for rural poor, marginalized and indigenous communities by regulating ecosystem services and their access to the community in times of drought and disaster [74] and summarized in Fig. 4.

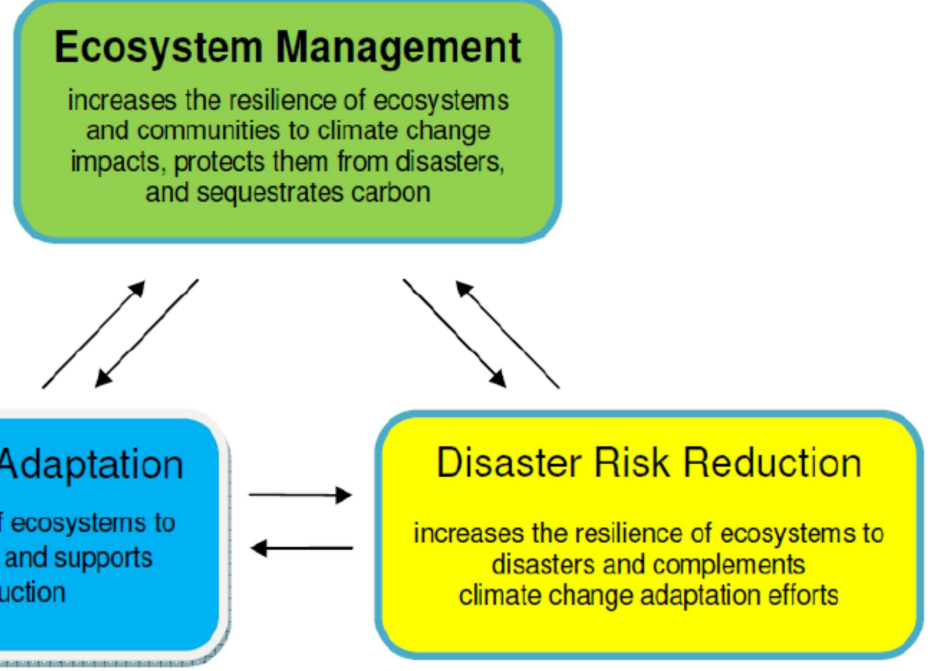

Figure 4. Ecosystems as a foundation in Disaster risk reduction and Climate Change Adaptation [64].

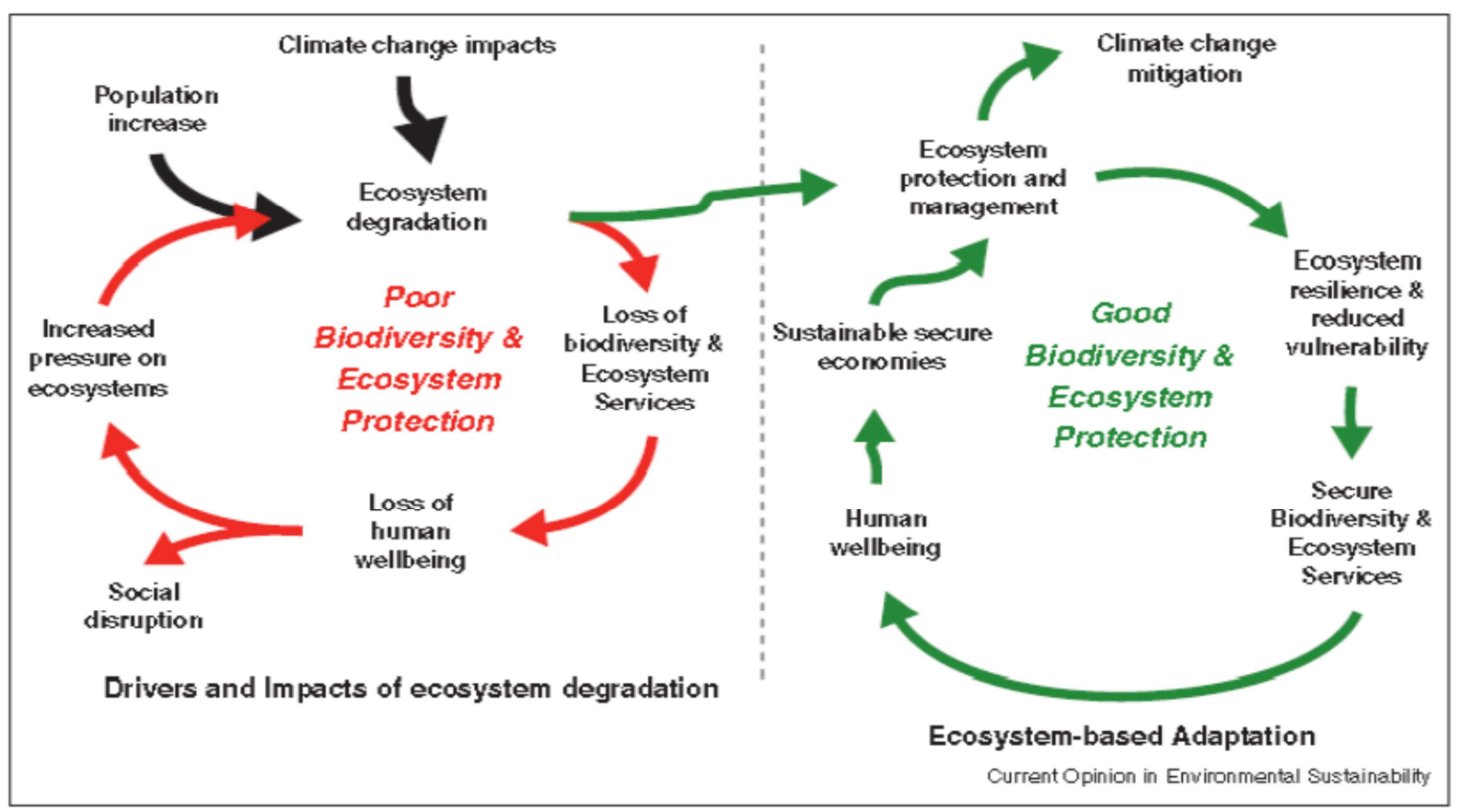

Figure 5. The Vicious Cycle of Poverty, Ecosystem Degradation and Climate Change [49]. 


\subsection{Ecosystem-Based Approach Conserves Biodiversity, Maintains Ecosystem Services and Resilience}

Maintaining high species diversity and functioning ecosystems across the wider terrestrial, freshwater and marine environment is essential to climate proofing and building resilience [26]; as they are effective in storing significant amount of carbon [64] and sustain unforeseen disturbances [26]. In effect, it is understood that biodiversity rich ecosystems are highly resilient to external shocks, such as extreme climatic events [64].

One of the objectives of ecosystem management is to maintain health and enhance resilience; whilst reducing vulnerability in the face of climate change. It creates substantial social, economic and cultural advantages, support biodiversity conservation and build on traditional knowledge and trends of indigenous people, including women participation [49]. Resilient ecosystems have a greater potential to mitigate and adapt to climate change and to reverse global warming. They resist and recover more easily from extreme weather events and provide a wide range of ecosystem services [26] Fig. 5.

\section{Conclusion}

It is real that global climate is changing at unprecedented rate resulting in considerable consequences on ecosystems and human well-being. Anthropogenic releases of greenhouse gases, mainly $\mathrm{CO} 2$ has warmed the Earth's surface; where its concentration has risen more linearly for the last 100 year (1906-2005) by $0.74^{\circ} \mathrm{C}$ than the corresponding period (1901$2000)$ of $0.6^{\circ} \mathrm{C}$. This has resulted in occurrences of extreme weather events, such as rising sea-levels, recurrent droughts, intensive hurricanes and floods, etc. It is uncertain to predict the potential of developmental sectors if environmental change continues. Unless ecosystems become resilient enough against environmental disturbances, no life could exist on this planet. Accordingly, ecosystem resilient should be built through adaptation and mitigation strategies so as to reverse current emissions as well as to adapt to live with uncertainty.

\section{References}

[1] (ACCCA, 2010) Farm - Level Climate change Perception and Adaptation in Drought Prone Areas of Tigray, Northern Ethiopia. Improving decision-making capacity of smallholder farmers in response to climate risk adaptation in three drought-prone districts of Tigray, northern Ethiopia Vol 3. Advancing capacity to Support Climate Change Adaptation (ACCCA), Mekelle, 2010.

[2] W. Adger, P. Neil, M. Kelly, and N. Huu, Living with Environmental Change: Social Vulnerability Adaptation, and Resilience in Vietnam. Rutledge, London, 2001.

[3] A. D. Alene, Improved production technology and efficiency of small holder farmers in Ethiopia: Extended Parametric and non-parametric approaches to production efficiency analysis.
$\mathrm{PhD}$ Thesis. Department of Agricultural Economics, Extension and Rural Development. University of Pretoria, South Africa, 2003.

[4] A. Bahadur, M. Ibrahim, and T. Tanner, The resilience renaissance? Unpacking of resilience for tackling climate change and disasters. Brighton, UK: Institute of Development Studies, 2010.

[5] K. Belay, Agricultural extension in Ethiopia: the case of participatory demonstration and training extension system. Journal of social development in Africa 18(1), 50-83, 2003.

[6] F. Berkes, Understanding uncertainty and reducing vulnerability: Lessons from resilience thinking. Natural Hazards 41: 283-295, 2007.

[7] R. Biggs, M. Schlüter, D. Biggs, E. L. Bohensky, S. BurnSilver, G. Cundill, V. Dakos, T. M. Daw, L. S. Evans, K. Kotschy, A. M. Leitch, C. Meek, A. Quinlan, C. RaudseppHearne, M. D. Robards, M. L. Schoon, L. Schultz, and P. C. West, Toward principles for enhancing the resilience of ecosystem services. Annual Review of Environment and Resources, 37: 421-448, 2007.

[8] F. Brand, Ecological resilience and its relevance within a theory of sustainable development. UFZ-Report 03/2005. UFZ Centre for Environmental Research, Leipzig, Germany.

[9] F. S. Brand, and K. Jax, Focusing the meaning(s) of resilience: Resilience as a descriptive concept and a boundary object. Ecology and Society 12, 1: 23, 2007.

[10] M. Cadman, C. Petersen, A. Driver, N. Sekhran, K. Maze, and S. Munzhedzi, Biodiversity for Development: South Africa's landscape approach to conserving biodiversity and promoting ecosystem resilience. South African National Biodiversity Institute, Pretoria, 2010.

[11] F. Capra, The Hidden Connections: A Science for Sustainable Living. New York: Anchor Books, 2002.

[12] S. Carpente, H. Mooney, J. Agard, D. Capistrano, R. DeFries, S. Diaz, T. Dietz, A. , A. Oteng-Yeboah, E. Pereira, C. Perrings, W. Reid, J. Sarukhan, R. Scholes, A. Whyte, Science for managing ecosystem services: Beyond the Millennium Ecosystem Assessment. Proceedingsof the Natural Academy of Science (106) 5: 1305-1312, 2009.

[13] S. R. Carpenter,J. J. Cole, J. R. Hodgson, J. F. Kitchell, M. L. Pace, D. Bad, K. L. Cottingham, T. E. Essington, J. N. Houser, and D. E. Schindler, Trophic cascades, nutrients and lake productivity: wholelake experiments. Ecological Monographs 71:163-186, 2001.

[14] Carpenter SR., et al. 2012. Program on ecosystem change and society: an international research strategy for integrated social-ecological systems, Curr Opin Environ Sustain, doi:10.1016/j.cosust.2012.01.00.

[15] CEEPA, Climate change and African agriculture. University of Pretoria, South Africa. Policy note No. 25, 2006.

[16] Convention on Biological Diversity (CBD), Global Biodiversity Outlook-3. Convention on Biological Diversity, 2010.

[17] CSA (Central Statistics Authority), The Federal Democratic Republic of Ethiopia Statistical abstract. Addis Ababa, Ethiopia, 2005. 
[18] Department for International Development (DFID) Defining Disaster Resilience: A DFID Approach Paper. Department for International Development: London, UK, 2011.

[19] T. T. Deressa, R. M. Hassan, C. Ringler, Perception of an adaptation to climate change by farmers in the Nile basin of Ethiopia. J Agri Sci 149:23-31, 2011.

[20] S. Devereux, Food security in Ethiopia: A discussion paper for DFID. Institute for Development Studies, Sussex, 2000.

[21] N. Dudley, S. Stolton, A. Belokurov, L. Krueger, N. Lopoukhine, K. MacKinnon, T. Sandwith, N. Sekhran, Natural Solutions: Protected areas helping people cope with climate change. IUCN-WCPA, TNC, UNDP, WCS, The World Bank, WWF, Gland, Switzerland, 2010.

[22] W. E. Easterling, P. K. Aggarwal, K .M. Batima, L. Brander, S. M. Erda, A. Howden, J. Kirilenko, J. F. Morton, J. Soussana, and F. N. Tubiello, Food, fibre and forest products. Climate Change 2007: Impacts, Adaptation and Vulnerability. Contribution of Working Group II to the Fourth Assessment Report of the Intergovernmental Panel on Climate Change, M.L. Parry, O.F. Canziani, J.P. Palutikof, P.J. van der Linden and C.E. Hanson, Eds., Cambridge University Press, Cambridge, UK, 273-313, 2007.

[23] [23]J. Eliasch, The Eliasch Review: Climate Change: Financing Global Forests, United Kingdom Office of Climate Change (OCC), London, UK, 2008.

[24] T. Elmqvist, C. Folke, M. Nystrom, G. Peterson, J. Bengtsson, B. Walker and J. Norberg, Response diversity, ecosystem change, and resilience. Frontiers in Ecology and the Environment 1, 488-494, 2003.

[25] C. S. Elton, The ecology of invasions by animals and plants. London:_Methuen, 1958.

[26] European Commission, White Paper: Adapting to climate change: Towards a European framework for action. COM(2009) 147 final, 2009.

[27] C. Folke, Resilience: The emergence of a perspective for social-ecological systems analyses. Global Environmental Change 16: 253-267, 2006.

[28] H. C. Godfray, I. R. Beddington, L. Crute, D. N. Haddad, J. F. Lawrence, J. Muir, S. Pretty, S. M. Robinson, and C. Toulmin, Food security: the challenge of feeding 9 billion people. Science 327:812, 2010.

[29] L. H. Gunderson, C. S. Holling, Panarchy: understanding the transformations in human and natural systems. Island Press, Washington, 2002.

[30] C. S. Holling, Resilience and Stability of Ecological Systems. Annual Review of Ecology and Systematics 4: 1-23, 1973.

[31] C. S. Holling, editor. Adaptive Environmental Assessment and Management. Wiley, London, 1978.

[32] T. Hughes, A. H. Baird, D. R. Bellwood, M. Card, S. R. Connolly, et al, Climate Change, Human Impacts, and the Resilience of Coral Reefs. Science 301: 929-933, 2003.

[33] Intergovernmental Panel on Climate Change (IPCC), "Working Group I Third Assessment Report." Cambridge University Press. Cambridge, UK. 881 pp, 2001.

[34] Intergovernmental Panel on Climate Change (IPCC), Climate Change 2001: Impacts, adaptation, and vulnerability.
Contribution of Working Group II to the Third Assessment Report of the Intergovernmental Panel on Climate Change. McCarthy, J.J., Canziani, O.F., Leary, N.A., Dokken D.J., and White, K.S. (Eds.), Cambridge University Press, Cambridge, 1032 pp, 2001a.

[35] Intergovernmental Panel on Climate Change (IPCC), Climate Change 2007: Synthesis Report, 52 pp (http://www.ipcc.ch/pdf/assessment-

report/ar4/syr/ar4_syr_spm.pdf), 2007) Date accessed: 22 February 2015.

[36] Intergovernmental Panel on Climate Change (IPCC), Climate Change 2014: Impacts, Adaptation, and Vulnerability. Part A: Global and Sectoral Aspects. Contribution of Working Group II to the Fifth Assessment Report of the Intergovernmental Panel on Climate Change [Field, C.B., V.R. Barros, D.J. Dokken, K.J. Mach, M.D. Mastrandrea, T.E. Bilir, M. Chatterjee, K.L. Ebi, Y.O. Estrada, R.C. Genova, B. Girma, E.S. Kissel, A.N. Levy, S. MacCracken, P.R. Mastrandrea, and L.L. White (eds)]. Cambridge University Press, Cambridge, United Kingdom and New York, NY, USA, 1132 pp, 2014.

[37] J. X. Kasperson, R. E. Kasperson, and B. L. Turner, Regions at Risk: Comparisons of Threatened Environments, 1995. United Nations University Press, NY.

[38] R. W. Kates, T. M. Parris, Long-term trends and a sustainability transition. In Proceedings of the National Academy of Sciences of the United States of America, 100:8062-8067, 2003.

[39] J. Kiehl, Lessons from the Earth's past. Science 2011, 331:158-159, 2011.

[40] S. Lautze, Y. Aklilu, A. Raven-Roberts, H. Young, G. Kebede, L. Leaning, Risk and Vulnerability in Ethiopia: Learning from the Past, Responding to the Present. Preparing for the Future, Addis Ababa, 2003.

[41] B. Locatelli, V. Evans, A. Wardell, A. Andrade, and R. Vignola, Forests and climate change in Latin America: linking adaptation and mitigation. Forests 2: 431-450, 2011.

[42] J. Lovelock, The Revenge of GAIA. New York: Basic Books, 2007.

[43] Y. Lu, R. Wang, Y. Zhang, H. Su, P. Wang, A. Jenkins, R. C. Ferrier, M. Bailey, and G. Squire, Ecosystem health towards sustainability._Ecosystem Health and Sustainability 1(1):2, 2015.

[44] S. B. Manyena, The concept of resilience revisited. Disasters, 30(4): 433-450, 2006.

[45] J. S. Mayunga, Understanding and applying the concept of community disaster resilience: A capital-based approach. Draft working paper prepared for the summer academy, Megacities as Hotspots of Risk: Social Vulnerability and Resilience Building, Munich, Germany, 22-28 July 2007.

[46] M. J. Metzger, M. A. Rounsevell, L. Acosta-Michlik, R. Leemans, D. Schroter, The vulnerability of Ecosystem services to land use change. Agric.Ecol.Environ.114, 69-85, 2006.

[47] Millennium Ecosystem Assessment (MEA) Ecosystems and Human Well-being: Synthesis. Millennium Ecosystem Assessment Series. Island Press and World Resources Institute. Washington, D.C, 2005. 
[48] M. Mortimore, W. M. Adams, Working the Sahel: environment and society in northern Nigeria. Routledge, London, 1999.

[49] R. Munang, I. Thiaw, K. Alverson, M. Mumba, J. Liu, and M. Rivington, Climate change and Ecosystem-based Adaptation: a new pragmatic approach to buffering climate change impacts, Curr Opin Environ Sustain, 2013.

[50] S. Naumann, G. Anzaldua, P. Berry, S. Burch, M. Davis, A. Frelih- Larsen, H. Gerdes, M. Sanders, Assessment of the potential of ecosystem-based approaches to climate change adaptation and mitigation in Europe. Final report to the European Commission, DG Environment. Ecologic Institute and Environmental Change Institute, Oxford University Centre for the Environment, 2011.

[51] C. Nellemann, M. MacDevette, T. Manders, B. Eickhout, B. Svihus, A. G. Prins, and B. P. Kaltenborn eds. The environmental food crisis: The environment's role in averting future food crises. A UNEP Rapid Response Assessment. Arendal, Norway: GRID-Arendal, United Nations Environment Programme, 2009.

[52] D. R. Nelson, W. N. Adger, and K. Brown, Adaptation to environmental change: Contributions of a resilience framework. Annual Review of Environment and Resources 32(1): 395-419, 2007.

[53] K. O’Brien, L. Sygna, R. Leichenko, W. N. Adger, J. Barnett, T. Mitchell, Disaster Risk Reduction, Climate Change Adaptation and Human Security. A Commissioned Report for the Norwegian Ministry of Foreign Affairs, 2008.

[54] E. Ostrom, A general framework for analyzing sustainability of socio-ecological systems. Science, 325: 419-422, 2009.

[55] Resilience Alliance, Resilience Available at: www.resalliance.org/576.php. Accessed on: 21/10/2015, 2002.

[56] Rockefeller FoundationBuilding climate change resilience. Rockefeller Foundation White Paper. Rockefeller Foundation: New York, USA, 2009.

[57] B. Smit, and O. Pilifosova, Adaptation to climate change in the context of sustainable development and equity. In: Climate Change 2001: Impacts, Adaptation and Vulnerability. Contribution of the Working Group II to the Third Assessment Report of the Intergovernmental Panel on Climate Change [McCarthy, J., O. Canziani, N. Leary, D. Dokken, and K. White (eds.)]. Cambridge University Press, Cambridge, UK and New York, NY, USA, pp. 879-912, 2001.

[58] South Africa Convention on Biological Diversity (SCBD), Connecting Biodiversity and Climate Change Mitigation and Adaptation: Report of the Second Ad Hoc Technical Expert Group on Biodiversity and Climate Change Montreal: SCBD, 2009.

[59] K. Strzepek, A. Mccluskey, District Level Hydro-climatic Time Series and Scenario Analysis to Assess the Impacts of Climate Change on Regional Water Resources and Agriculture in Africa. CEEPA Discussion Paper No. 13, Pretoria, South Africa, 2006.

[60] A. Tadege, Climate Change National Adaptation Program of Action (NAPA) of Ethiopia. NMS (National Meteorological Agency), Federal Democratic Republic of Ethiopia Addis Ababa, 2007.
[61] Y. Tessema, S. C. Awoke, and G. S. Endris, Understanding the process of adaptation to climate change by small-holder farmers: the case of east Hararghe Zone, Ethiopia. Agricultural and Food Economics, 1: 13, 2013.

[62] E. L. Tompkins, and W. N. Adger, Building resilience to climate change through adaptive management of natural resources, Tyndall Centre Working Paper 27, 2003.

[63] J.Twigg, Characteristics of Disaster- Resilient Community. University College London: London, UK, 2009.

[64] United Nations Environment Programme (UNEP), The Role of Ecosystem Management in Climate Change Adaptation and Disaster Risk Reduction. UNEP Copenhagen Discussion Series, 2009.

[65] United Nations Framework Convention for Climate Change (UNFCC), Report of the Conference of the Parties on its thirteenth session, held in Bali from 3 to 15 December 2007.

[66] United Nations Framework Convention on Climate Change (UNFCCC), United Nations Framework Convention on Climate Change: Ecosystem-based approaches to adaptation: compilation of information. Nairobi, Kenya, 2011.

[67] United Nations Framework Convention on Climate Change (UNFCCC), United Nations Framework Convention on Climate Change: Handbook. UNFCCC Secretariat. Bonn, Germany, 2006.

[68] United Nations International strategy for Disaster Reduction (UNISDR), Global Assessment Report on Disaster Risk Reduction. United Nations International Strategy for Disaster Reduction Secretariat, Geneva, Switzerland, 207 pp, 2009.

[69] N. Uy, R. Shaw, The role of ecosystems in climate change adaptation and disaster risk reduction. In Community, Environment and Disaster Risk Management. Edited by Uy N, Shaw R. Emerald Group Publishing Limited, 41-59, 2012.

[70] B. Walker, and D. Salt, Resilience Thinking: Sustaining Ecosystems and People in a Changing World. Island press, Washington DC, 2006.

[71] B. Walker, C. S. Holling, S. R. Carpenter, and A. Kinzig, Resilience, adaptability and transformability in socialecological systems. Ecology and Society 9(2), 2004.

[72] Water Resource Institute, United Nations Development Programme, United Nations Environmental Programme and World Bank (WRI/UNDP/UNEP/World Bank). World Resources, Roots of Resilience - Growing the Wealth of the Poor. Washington: World Resources Institute, 262p. http://www.wri.org/publication/world-resources-2008-rootsof-resilience, 2008.

[73] T. Wheeler, and J. Von Braun, Climate change impacts on global food security. Science 341:508-513.-818, 2013.

[74] World Bank, Convenient solutions for an inconvenient truth: Ecosystem-based Approach to Climate Change. The World Bank, Washington D.C, 2009.

[75] C. T. Yirga CT, The dynamics of soil degradation and incentives for optimal management in Central Highlands of Ethiopia. University of Pretoria, Pretoria, South Africa, 2007. 